\title{
An assessment instrument of mind map product to assess students' creative thinking skill
}

\author{
${ }^{* 1}$ Regina Ratih Fardhila; ${ }^{2}$ Edi Istiyono \\ ${ }^{1,2}$ Department of Educational Research and Evaluation, \\ Graduate School of Universitas Negeri Yogyakarta \\ Jl. Colombo No. 1, Karangmalang, Depok, Sleman, D. I. Yogyakarta 55281, Indonesia \\ *Corresponding Author. E-mail: reginaratihfardhila.2017@student.uny.ac.id \\ Submitted: 21 December 2018 | Revised: 22 April 2019 | Accepted:06 May 2019
}

\begin{abstract}
Education is now more demanding for students to think more at a higher and more complex level. Mind map also builds creativity because it is more flexible in expressing ideas. The result of need assessment was the teachers cannot put on equation about creative thinking in test because the input of heterogeneous students, but they carried out project and practicum assessments, which required relatively much time, place and equipment. Therefore, the researchers develop instruments for assessing students' creative thinking skills at the high-school level trough mind map on valid and reliable biology subjects so that teachers can use them as a more efficient assessment tool. This research employed research and development (R\&D) method; adapting ADDIE (Analyze, Design, Development, Implementation, and Evaluation) model. Content validity was achieved using the Lawshe method; CVR formula, while the construct validity was achieved through exploratory factor analysis with the SPSS program and then confirm with confirmatory factor analysis using Lisrel program. It is found out that the construct validity was proven by the significant value of MSA and Loading Factor value. Suitability of the construct model with the data was indicate with p-value $=0.68(\geq 0.05)$; Root Mean Square Error Approximation $=0.00(\leq 0.08)$; and Goodness of Fit Index $=0.94(>0.90)$. The reliability of the instrument is 0.774 , which means reliable. The assessment instrument of mind map product to assess creative thinking skill of students at the high school level in biology subjects has ten fit items in four factors; Flexibility, Elaboration, Originality, and Fluency.
\end{abstract}

Keywords: product assessment, mind map, creative thinking skill

Permalink/DOI: https://doi.org/10.21831/reid.v5i1.22525

\section{Introduction}

Education is now demanding students to think at a higher and more complex level, which is a high level of thinking on Bloom's taxonomy, namely analysis, evaluation, and creation. The top three levels of Bloom's taxonomy are called High Order Thinking Skills (HOTS). It is in line with the general objectives of 2013 curriculum which is to prepare Indonesian people to have the ability to live as individuals and citizens who are faithful, productive, creative, innovative and affective and able to contribute to the life of the world, nation, state, and world civilization.
The ability to think creatively becomes one of high-level thinking (HOTS). Creative thinking is generally regarded as gathering information to produce new understandings, concepts, or ideas (Moore, 2015, p. 380). The ability to think creatively creates a creative generation that has the potential to solve social problems and environmental issues (Yusnaeni, Corebima, Susilo, \& Zubaidah, 2017). Creative thinking will produce fluency, flexibility, and originality (Buzan, 2011). Fluency in question will show speed in forming new ideas. Flexibility will indicate a person's ability to consider ideas and reverse the ideas that previously existed. Originality will form 
unique ideas. A creative person can think fluently, flexibly, has flexibility of thinking and originality, and also elaboration (DePorter \& Henarcki, 2010, p. 292).

Learning assessment has an essential role in generating students' creative thinking skills because in general, a person's ability will be seen if there is an assessment activity aimed at assessing that ability. More specifically, the assessment or assessment process in education includes collecting evidence about students' learning achievements both through tests, observations, and also the work of the students.

Creative thinking is closely related to the creativity needed in biology learning because in biology learning, a student not only learns concepts, laws, principles, and facts but also learns about knowledge in the form of work craze, obtaining information on how science works and thinking skills (Herlina \& Qurbaniah, 2017). Biology is one of the science aspects, so biology learning is demanded to make students have creativity in science process skill (Putri, Paidi, \& Subali, 2016). Previous research from Putri et al. (2016) also stated that there was a relationship between divergent thinking ability of science process biology aspect of an elementary student, where divergent thinking ability is one of the creativity indicators. According to the creative ability model of Guilford (1950), someone creative has the characteristics of fluent thinking ability, flexible thinking ability (flexibility), original ability to think (originality) and elaboration ability.

Preliminary research data was obtained through interviews with four biology teachers in three different schools, namely Purbalingga 1 State High School, Purbalingga 2 State High School, and Purbalingga 1 Muhammadiyah High School. The four stated that they had not been able to assess students' creative thinking ability by conducting tests, both daily tests, and end semester assessments. They assess the ability to think creatively through projects and practicum, which are carried out 1-4 times in one semester, and of course, require a lot of time and equipment.

The results of observations on the grids and daily repetition questions as well as the final semester assessment of biology lessons used by the three schools showed that there were no questions that measured the ability to think creatively. Three teachers revealed the absence of a problem that measures creative thinking ability because the input of heterogeneous students is due, since the enactment of students admission by using an official letter stating that a student comes from a financially-dependent family, in the academic year of $2017 / 2018$. Further, student admission in the academic year of 2018/2019 follows the Regulation of Minister of Education and Culture, No. 14 of 2018, on Student Admissions, which states that the zoning system of the distance between residence and school is the main criterion. With the existence of these regulations, the input of the students is increasingly heterogeneous.

From the result of need assessment, it is known that teacher needs a new way to assess creative thinking skill. Teachers need an assessment that more efficient; less time and equipment, and also can assess that heterogeneous student.

Mind maps can also be called thinking maps, which are pattern languages that allow all learners to have a language of visual-verbal cognition, to enable a deeper capacity to see, change, imagine, and improve their thinking skills (Hyerle, 2012, p. 1). Mind maps can also be called concept maps. Concept maps are visual presentations of concept connections and hierarchical organizations (Santrock, 2014, p. 5). Mind maps can be used as a tool to determine not only what has been studied or known by someone, but also how someone thinks about the information. The assessment using mind maps allows us to know how students think in receiving and processing information in learning.

Mind map also builds creativity because it is more flexible in expressing ideas. Presenting all relevant or relevant topics in the same mind map, detailing and connecting them through images, symbols, and warmth, can improve memory, it is easier to understand, and more effective in time and increase productivity (Murley, 2007). Another advantage of mind maps is that mind maps will provide a comprehensive view of the subject matter or 
a large area, allowing us to plan routes or make choices, gather large amounts of data somewhere, encourage problem-solving by letting us see the path of creative breakthroughs, and fun to see, read, digest and remember (Putri, 2016).

Several previous research concerning the relationship between mind maps and the ability to think creatively has been carried out. A research which is conducted by Sari and Jarnawi (2008) states that learning through creative mind maps can improve creativity and student connections to be better. This research describes how creative mind map affects the students' creativity with pre-test and post-test control group design. Another research conducted by Putri (2016) states that mind maps can be used as an evaluation tool for students' creative thinking abilities after learning by mind map concepts in experimental classes. Other research on mind maps is carried out by Çoban and Tokatlı (2017), which states that mind mapping techniques affect a person's creativity, especially in music lessons. This is experimental research. Three of those previous researches have not developed an instrument to measure creative thinking skill.

There are also some previous researches that have developed an instrument to measure creative thinking skill. Research by Hartati, Asrial, and Ernawati (2017) develop an instrument to measure students' creative thinking skill in chemistry subject; the instrument is a subjective test instrument. It uses a development model proposed by Supardi, Haryanto, and Suhendri (2014). The construct validity was not using Exploratory Factor Analysis (EFA), and the content validity was not using Lawshe (CVR) either Aiken's method. Another research from Kristiani, Mayasari, and Kurniadi (2017) concludes that instrument developed is a subjective test instrument in the physics subject. It used a 4-D model. This research used Lawshe method for content validity, but it does not use EFA for construct validity. From the two previous researches which developed an instrument to measure creative thinking skill, there were have not developed a non-test instrument which used Lawshe method for content validity also EFA for construct validity. Whereas, to compile an instrument, validity of content and construct based on the existing theory is needed to produce a truly valid instrument. Both of them also have not counted the instrument's estimate of reliability. Therefore, in this research, EFA was used because the researchers want to know that the indicators made are included in the correct factors or latent variables.

Biology is one of the sciences in which, in its learning process, it needs to be more than just knowing, but also having to understand. In addition, finding out how students think in processing information also needs to be considered.

Mind map explanation is the basis that with mind maps, students' creative thinking skills can be assessed. The use of mind maps is expected to be able to see students' creative thinking abilities in processing biology learning material. Trough mind map, teacher can assess the students' creative thinking skill.

The previous explanation requires assessment tools that do not need relatively much time and equipment and can measure the creative thinking skills of heterogeneous students. This consideration becomes the basis of the researchers to develop instruments to assess students 'creative thinking abilities through mind maps on valid and reliable biology subjects so that they can be used by educators or teachers as a more efficient assessment tool for students' creative thinking skills.

Thus, the objective of this research are: (1) to develop an instrument to measure student's creative thinking in biology subject, and (2) to find out the validity and reliability of the instrument to measure student's creative thinking skill in biology subject.

This research is hoped to be a reference for a teacher who wants to develop an assessment instrument. The instrument produced in this research can be used by the teacher to assess students' creative thinking skill, especially in biology subject.

\section{Method}

The method used in this study is research and development ( $\&$ \& $)$ or better known as research and development. This 
study develops an instrument for assessing mind map products to assess students' creative thinking skills, especially the senior high school level in biology subjects. The development model used in this research is ADDIE (Analyze, Design, Development, Implementation, and Evaluation). Random purposive sampling technique was used to choose the subjects for trying the instrument. The samples are three classes of XI grade science students of Madrasah Aliyah Negeri (MAN) 3 Sleman, Yogyakarta.

The data collected are in the form of quantitative and qualitative data. Quantitative data were collected from expert validation questionnaire for content validity and data from the result of students' mind map for validating the construct validity. Qualitative data were collected from expert recommendation during content validity.

The analysis (analyze) stage is a stage where researchers conduct a need assessment of products, by conducting interviews with biology teachers as well as observing the grids and daily test questions as well as the final semester assessment. Need assessment results on assessment instruments for mind map products to assess students' creative thinking skills at high school level in biology, namely instruments needed by biology teachers as a more practical and effective assessment tool in addition to project appraisal and practicum to assess thinking skills creative high school students in biology subjects. The results of the elaboration of aspects based on conceptual and operational definitions are then made as statement points, arranged in the instrument lattice. There are 21 statement items arranged in the initial design of this instrument. Scoring technique used is rating scale; 4 (very good), 3 (good), 2 (enough), and 1 (less). Each statement has its own assessment criteria, which are outlined in the assessment rubric.

The design phase is the stage where researchers design products in the form of assessment instruments of mind map product to assess students' creative thinking skills in biology subjects. The researchers designed the format of instrument grids, assessment rubrics, assessment sheets, and scoring techniques. Instrument design is formed based on conceptual and operational definitions. Conceptual and operational definitions also determine indicators that will be developed into statement items to measure students' creative thinking ability through mind maps (Table 1). Also, at this stage, researchers also plan who will become the instrument validator (rater), which will validate the contents of the instrument.

Table 1. Aspects, sub-aspects, and indicators of mind map to assess creative thinking skill

\begin{tabular}{|c|c|c|c|}
\hline & Aspect & Sub-aspect & Item Indicator \\
\hline A. & Originality & $\begin{array}{l}\text { A.1 Making distinctive characteris- } \\
\text { tics } \\
\text { A.2 Add a symbol combination }\end{array}$ & $\begin{array}{l}\text { A.1.1 Using keywords that are their own characteristics } \\
\text { A.1.2 Drawing patterns that are distinctive } \\
\text { A.2.1 Add symbols or images } \\
\text { A.2.2 Add a color combination }\end{array}$ \\
\hline B. & Fluency & $\begin{array}{l}\text { B.1 Pour ideas } \\
\text { B.2 Work fast }\end{array}$ & $\begin{array}{l}\text { B.1.1 Write down all material concepts } \\
\text { B.1.2 Write down problems in daily life } \\
\text { B.2.1 Pour the concept in a relatively short time } \\
\text { B.2.2 Complete a mind map in a relatively short time }\end{array}$ \\
\hline C. & Flexibility & $\begin{array}{l}\text { C.1 Develop the concept of mate- } \\
\text { rial } \\
\text { C.2 Add a solution to the problem }\end{array}$ & $\begin{array}{l}\text { C.1.1 Add personal opinion } \\
\text { C.1.2 Add material references } \\
\text { C.2.1 Write down solutions to problems in everyday } \\
\text { life }\end{array}$ \\
\hline D. & Elaboration & $\begin{array}{l}\text { D. } 1 \text { Describe the concept in depth } \\
\text { D. } 2 \text { Describes concepts with rele- } \\
\text { vant components } \\
\text { D. } 3 \text { Contact line } \\
\text { D. } 4 \text { Readability of idea relations } \\
\text { between concepts }\end{array}$ & $\begin{array}{l}\text { D.1.1 Write in detail the concept of matter } \\
\text { D.2.1 Write concepts with relevant components } \\
\text { D.3.1 The line can be read clearly } \\
\text { D.4.1 The relationship between ideas is easy to under- } \\
\text { stand }\end{array}$ \\
\hline
\end{tabular}


Development is the next stage, in which the researchers start developing the instrument, as well as conducting content validation on the instrument. The method used to determine the content validity of mind-map product assessment instruments to assess the ability to think creatively is the Lawshe method. Rater or Subject Matter Expert who was involved in the determination of the content index of the content for this amounted to nine people. The formula used to determine the ratio of content validity ratio (CVR) is as follows:

$$
C V R=\frac{(2 n e)}{n}-1
$$

Notes:

ne : number of rater which states essence

$\mathrm{N}$ : the total number of rater

The range of CVR values is -1.00 to 1.00 so that when CVR $>0.00$, an item is declared valid because more than half ( $>50 \%$ ) rater or Subject Matter Expert states that the item is essential (Azwar, 2012, p. 114). Data regarding item eligibility through content validation, obtained by validation sheet. Instruments that have been validated in the content are revised, so they are ready to be tested in the field. Implementation of the instrument (implementation), is the next step. The instrument was tested in the field to assess mind maps by biology teachers. The instrument was tested to assess the mind map created by 95 remaining XI Science. Determination of the sample was done by simple random sampling technique. The results of the field trial then became the basis for construct validation of the instrument, as well as testing the reliability of the instrument.

Construct validity explains the extent of the consistency of test performance with the constructs in a particular theoretical consideration (Hudha \& Mardapi, 2018). The test of construct validity and reliability is carried out at the evaluation stage, the results of which state the feasibility of the instrument used to assess mind maps to determine students' creative thinking ability in biology subjects. Construct validity is done by Exploratory Factor Analysis (EFA) and then confirmed by Confirmatory Factor Analysis (CFA).
Exploratory factor analysis or principal component analysis (PCA) is a factor analysis technique in which several factors will be formed in the form of latent variables that cannot be determined before the analysis is carried out (Yong \& Pearce, 2013, p. 79). Exploratory factor analysis was carried out using the SPSS program.

This analysis begins by testing the adequacy of the sample used in the analysis through the KMO (Kaiser-Mayer-Olkin) test. If the $\mathrm{KMO}$ value is between 0.5 to 1 , then it is indicated that factor analysis is appropriate to use and can be used for further analysis (Bilson, 2005, p. 123). Then, look at the antiimage value or see the MSA for each item. The MSA value for each variable can be seen diagonally on the anti-image correlation in the diagonal part of the matrix. If one or several initial variables individually have MSA values less than 0.5 , the variable is excluded from the analysis process (Bilson, 2005, p. 123). Calculate the eigenvalue, which is then used to calculate the percentage of variance that is explained, while drawing the scree plot, and grouping the items on the factors formed after the analysis. Factors that have eigenvalues greater than or equal to 1 will be maintained, and factors that have eigenvalues less than 1 will not be included in the model because variables with values less than 1 are not better than the original variables (Supranto, 2004).

The reliability testing technique which was used is Cronbach's Alpha, which is a coefficient that describes how well the items in a set are positively correlated with each other (Azwar, 2004). Reliability coefficients (Cronbach's Alpha) range from a score of 0.00 to 1.00 with the assumption that the closer to 1.00 , the more reliable the measuring instrument is (Azwar, 2004, p. 78).

Confirmatory Factor Analysis (CFA) is a method of factor analysis which is used when researchers know the structure of a latent factor (Laili \& Otok, 2014). CFA was used to confirm that the estimates model that was formed during exploratory analysis was fit. CFA was done using Lisrel program. The result of the CFA produced a standardized loading factor (SLF) and was determined as 
the construct validity. When the SLF value of the indicator is over 0.30, the indicator is then considered as significant (Igbaria, Zinatelli, Cragg, \& Cavaye, 1997, p. 290). Making it simpler, the ADDIE-model steps which were undertaken by the researchers are presented in Figure 1.

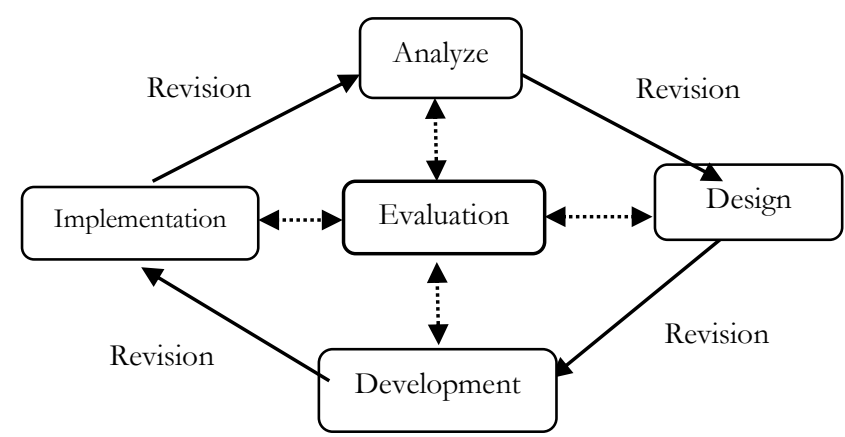

Figure 1. Steps for research and development of ADDIE models (Sugiyono, 2015, p. 39).

\section{Findings and Discussion}

\section{Findings}

The statement items that have been made subsequently are tested for content validity by the Lawshe method, involving nine raters. Calculations were done using the CVR formula. Of the 21 items submitted, there were three items declared invalid after the content validity was calculated, namely items 10, 14, and 16 (Table 2). The assessment results from rater are not just numbers but also some suggestions for improving grain quality. After revising, 18 items are valid to be tested.

The results of field trials or implementation of instruments in the field are used for the construct validity of the instrument. Construct validity was carried out using exploratory factor analysis. The analysis was carried out with SPSS program.

Table 2. Calculation results of content validity

\begin{tabular}{|c|c|c|c|c|c|c|c|c|c|c|c|}
\hline \multirow{2}{*}{ Item } & \multicolumn{9}{|c|}{ Rater } & \multirow{2}{*}{ CVR } & \multirow{2}{*}{ Validity } \\
\hline & 1 & 2 & 3 & 4 & 5 & 6 & 7 & 8 & 9 & & \\
\hline 1 & 3 & 3 & 3 & 3 & 3 & 3 & 3 & 3 & 3 & 1 & valid \\
\hline 2 & 2 & 3 & 3 & 3 & 3 & 3 & 3 & 3 & 3 & 0.78 & valid \\
\hline 3 & 3 & 3 & 3 & 3 & 3 & 3 & 3 & 3 & 3 & 1 & valid \\
\hline 4 & 3 & 3 & 3 & 3 & 3 & 3 & 3 & 3 & 3 & 1 & valid \\
\hline 5 & 3 & 3 & 3 & 3 & 3 & 3 & 3 & 2 & 3 & 0.78 & valid \\
\hline 6 & 3 & 3 & 3 & 3 & 3 & 3 & 3 & 3 & 3 & 1 & valid \\
\hline 7 & 3 & 3 & 3 & 3 & 3 & 3 & 3 & 1 & 3 & 0.78 & valid \\
\hline 8 & 3 & 3 & 3 & 2 & 3 & 3 & 3 & 3 & 3 & 0.78 & valid \\
\hline 9 & 3 & 3 & 2 & 3 & 3 & 3 & 3 & 3 & 3 & 0.78 & valid \\
\hline 10 & 2 & 3 & 2 & 3 & 2 & 2 & 3 & 3 & 2 & -0.11 & invalid \\
\hline 11 & 3 & 3 & 2 & 3 & 3 & 3 & 3 & 3 & 3 & 0.78 & valid \\
\hline 12 & 3 & 3 & 3 & 3 & 3 & 3 & 3 & 3 & 3 & 1 & valid \\
\hline 13 & 3 & 3 & 3 & 2 & 3 & 3 & 3 & 3 & 3 & 0.78 & valid \\
\hline 14 & 2 & 2 & 3 & 2 & 3 & 3 & 3 & 1 & 2 & -0.11 & invalid \\
\hline 15 & 3 & 3 & 3 & 3 & 3 & 3 & 3 & 3 & 3 & 1 & valid \\
\hline 16 & 2 & 3 & 3 & 3 & 2 & 2 & 3 & 1 & 2 & -0.11 & invalid \\
\hline 17 & 3 & 3 & 3 & 3 & 3 & 3 & 3 & 3 & 3 & 1 & valid \\
\hline 18 & 3 & 3 & 3 & 3 & 3 & 3 & 3 & 3 & 3 & 1 & valid \\
\hline 19 & 3 & 3 & 3 & 3 & 3 & 3 & 3 & 3 & 3 & 1 & valid \\
\hline 20 & 3 & 3 & 3 & 3 & 3 & 3 & 3 & 3 & 3 & 1 & valid \\
\hline 21 & 2 & 3 & 3 & 3 & 3 & 3 & 3 & 1 & 3 & 0.56 & valid \\
\hline
\end{tabular}




\section{Exploratory Factor Analysis}

The first explanation begins with the results of KMO and Bartlett's test. The results of the sample adequacy factor analysis show chi-square values in Bartlett test of 456.795 with a degree of freedom 153 and a p-value of $<0.01$. The Kaiser-Meyer-Olkin measure of sampling adequacy (KMO) was 0.839, which is greater than 0.5 . If the $\mathrm{KMO}$ value is between 0.5 to 1 , it means that the factor analysis is right.

MSA (Measure of Sampling Adequacy) can be seen from anti-image correlation diagonal matrices of each variable. The antiimage correlation value is marked by a superscript of 'a.' MSA analysis results show that all items have a relationship with other initial variables, so there no one item must be removed from the analysis process. It is in line with the statement of Bilson (2005, p. 123), if one or several initial variables individually have MSA values less than 0.5 , then the variable is excluded from the analysis process. The method often used in exploratory factor analysis for factor formation is the principal component method with orthogonal rotation. The specific purpose of the principal component analysis method is to know the structure underlying the initial variables in the analysis and simplify the structure of the initial set of variables through data reduction.

Based on the eigenvalues and the components of the factor analysis variance with SPSS, it was found that the data obtained from the mind map product assessment using the instruments used contained 5 Eigenvalues greater than 1, so that it can be said that the instrument of mind map products contains 5 factors, but only 4 factors were expected. After two items that had the lowest MSA values were issued (item 4 and 11), re-analysis was carried out to produce the number of expected factors. The result of the re-analysis of KMO and Bartlett's Test is in Table 3.

Table 3. Result of KMO and Bartlett's Test

\begin{tabular}{lll}
\hline \multicolumn{2}{c}{ KMO and Bartlett's test } \\
\hline $\begin{array}{l}\text { Kaiser-Meyer-Olkin Measure of Sampling } \\
\text { Adequacy. }\end{array}$ & .857 \\
$\begin{array}{ll}\text { Bartlett's Test of } \\
\text { Sphericity }\end{array}$ & Approx. Chi-Square & 456.795 \\
& df & 120 \\
& Sig. & .000 \\
\hline
\end{tabular}

Table 3 shows that the $\mathrm{KMO}$ value was 0.857 ; indicating that it is very good. Bartlett's Test Sphericity value was 456.795 at the degree of freedom 120 and signification 0.000 , so it was very good. Based on eigenvalues, reanalysis produce four eigenvalues that were greater than 1 , so the instrument of mind map product contains four factors as expected. Of the four factors, there was $56.116 \%$ variance explained.

Scree plot is a graph that shows the relationship between factors with their eigenvalues. Determining these criteria is done by plotting the eigenvalue of the number of factors to be extracted. The eigenvalues are plotted in the vertical direction, while the number of factors is plotted in the horizontal direction. The number of factors in this criterion is determined based on the decrease in the plot of the eigenvalues. On the scree plot generated from the analysis (Figure 2), shows four plot drop points, so that four factors were formed from 16 variables (items).

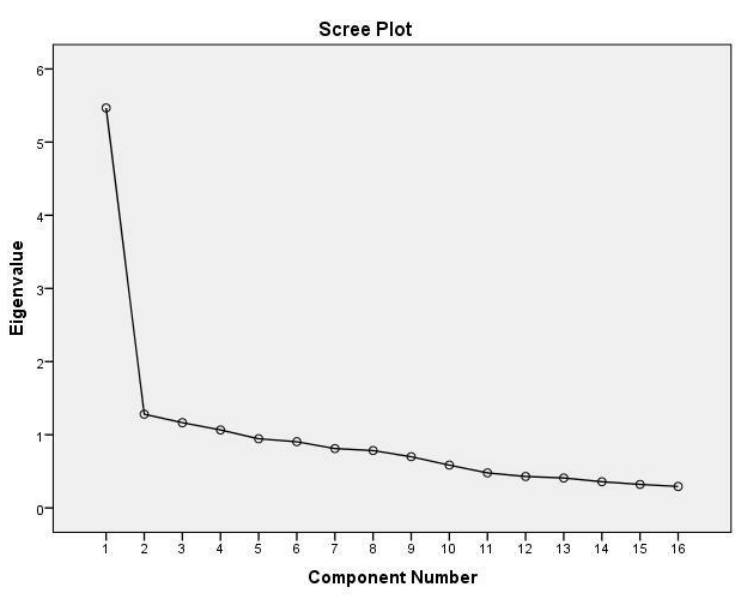

Figure 2. Scree plot

Four components or factors have been formed after the analysis process, then rotating these factors. The main objective of the rotation process is to achieve simplicity with factors and increase the ability of interpretation. The method used is the varimax method, which focuses its analysis on simplifying the column matrix factor. In this method, there is a tendency to produce several high factor loading values (close to -1 or +1 ) and some factor loading values close to 0 in each matrix column - a significant loading factor if $\geq 0.5$. 
We will look at the component matrices in Table 4 that have been rotated by variables or which items are worth $\geq 0.5$, which will be incorporated into the factors or components that have been formed. Grouping items or variables in each component are presented in Table 5.

Table 4. Rotated component matrix ${ }^{a}$

\begin{tabular}{lllll}
\hline & \multicolumn{4}{c}{ Component } \\
\cline { 2 - 5 } & $\mathbf{1}$ & $\mathbf{2}$ & $\mathbf{3}$ & $\mathbf{4}$ \\
\hline item1 & .061 & .355 & .703 & -.239 \\
item2 & .737 & .202 & -.010 & -.054 \\
item3 & .524 & .108 & .465 & .162 \\
Item5 & -.607 & -.234 & -.125 & -.152 \\
Item6 & .102 & -.089 & .827 & .100 \\
Item7 & .328 & .499 & .113 & -.240 \\
Item8 & .791 & .082 & .017 & -.032 \\
Item9 & -.029 & .759 & .196 & .224 \\
Item10 & .131 & .092 & .013 & .818 \\
item12 & -.637 & -.266 & -.115 & -.170 \\
item13 & -.551 & -.275 & -.374 & -.080 \\
item14 & -.298 & -.634 & .003 & -.067 \\
item15 & .185 & .484 & -.017 & -.233 \\
item16 & .481 & .585 & .190 & .142 \\
item17 & .387 & .609 & .025 & .203 \\
item18 & .561 & .379 & .146 & -.229 \\
\hline Nem & & & &
\end{tabular}

Notes:

Extraction method: Principal component analysis. Rotation method: Varimax with Kaiser normalization.

a. Rotation converged in 5 literations.

Table 5. Grouping items

\begin{tabular}{lcccc}
\hline Factor & $\mathbf{1}$ & $\mathbf{2}$ & $\mathbf{3}$ & $\mathbf{4}$ \\
\hline Item & $2,3,8,18$ & $9,16,17$ & 1,6 & 10 \\
\hline
\end{tabular}

Sixteen items were grouped into four factors formed during the analysis. Factor 1 consists of four items; factor 2 consists of three items; factor 3 consists of two items, and factor 4 consists of one item. There are six items, points $5,7,12,13,14$, and 15 , which do not belong to any group of factors. These six items will then be eliminated because there is no connection with the other items. Thus, from 16 items after factor analysis, six items must be removed.

The naming of each factor is the next step. Factor naming is based on the characteristics of each item or variable that is a member of the factor (Table 6). After we have the item which we will use, the next step is to find out the reliability of the instrument. Reliability of the instrument is 0.774 .

\section{Confirmatory Factor Analysis}

The conceptual construct model design which had been formed during exploratory analysis was then analyzed with second-order CFA. The result is presented in Figure 3. The analysis result shows that the model designed complies with the goodness of fit statistics. The model fit of the instrument is indicated by the $p$-value $=0.68(\mathrm{p}>0.05)$, RMSEA $=$ 0.00 (RMSEA $<0.08$ ) and Goodness of Fit Index $=0.94$. Based on data, $\mathrm{p}$-value and RMSEA were successfully met, so that it is indicated that this model was fit with the data.

Table 6. Naming factor

\begin{tabular}{|c|c|c|}
\hline Items & Factor & Name of Factor \\
\hline $\begin{array}{l}\text { 2. Adjust the proportion of the use of keywords and } \\
\text { sentences }\end{array}$ & 1 & Flexibility \\
\hline 3. Drawing different pattern from others & & \\
\hline $\begin{array}{l}\text { 8. The concept of the material outlined is easy to } \\
\text { understand }\end{array}$ & & \\
\hline $\begin{array}{l}\text { 18. Relationship between ideas help understand the } \\
\text { whole contents of the mind map }\end{array}$ & & \\
\hline $\begin{array}{l}\text { 9. Mention examples of common problems } \\
\text { 16. Components used in detailing concepts relevant } \\
\text { to the material }\end{array}$ & 2 & Elaboration \\
\hline 17. Write material with many branches & & \\
\hline 1. Use keywords that are different from others & 3 & Originality \\
\hline 6. Use various colors in the mind map & & \\
\hline $\begin{array}{l}\text { 10. Explain the concept of the material in a } \\
\text { maximum of } 30 \text { minutes }\end{array}$ & 4 & Fluency \\
\hline
\end{tabular}




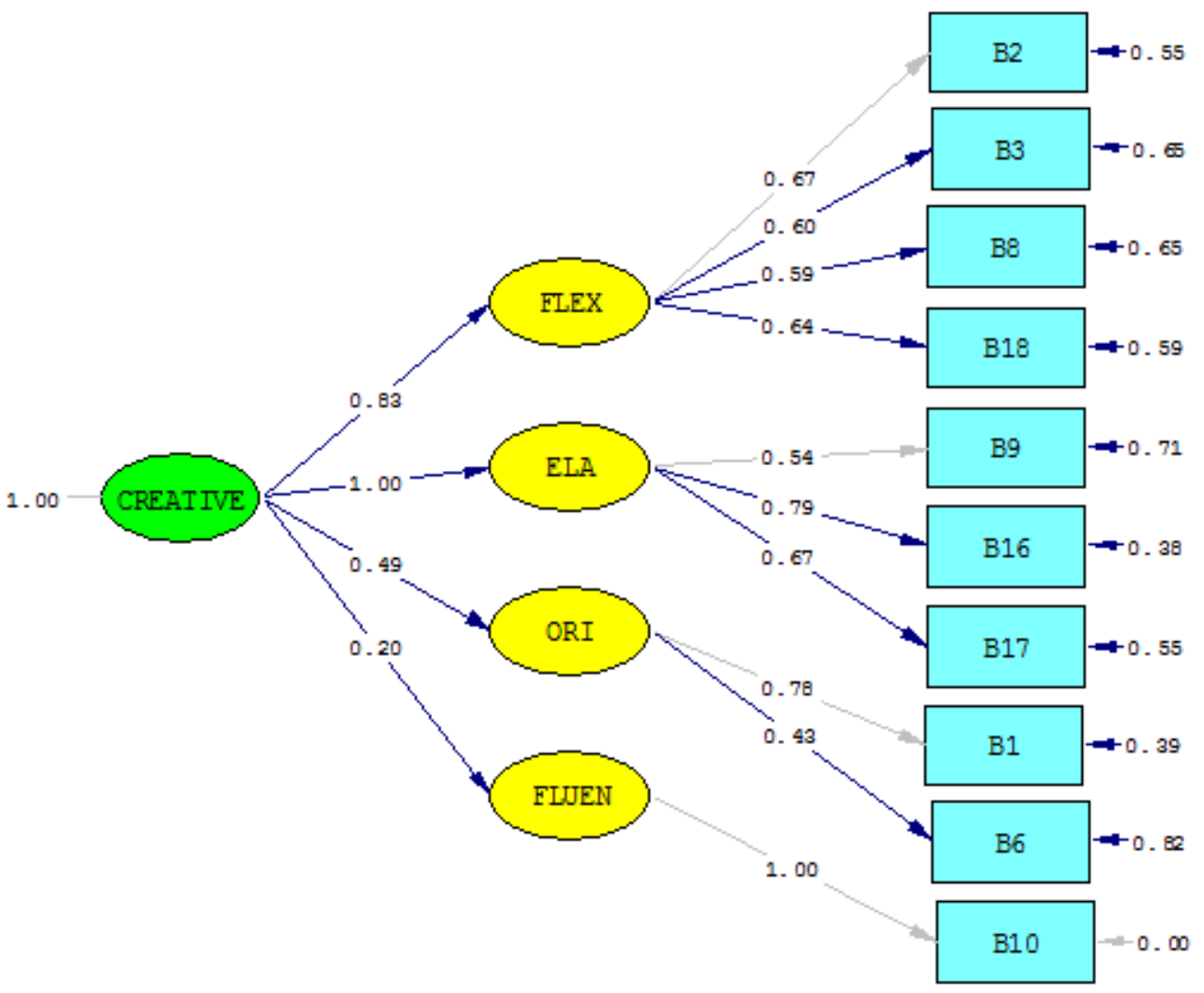

Chi-3quare $=28.66, \mathrm{df}=32, \mathrm{P}-\mathrm{value}=0.63614, \mathrm{RMSEA}=0.000$

Figure 3. Path diagram of second order analysis output

Table 7. Result of second order CFA of the instrument of mind map product with 16 item

\begin{tabular}{lllll}
\hline Aspects & Item & SLF & $\mathbf{R}^{\mathbf{2}}$ & Notes \\
\hline Flexibility & $\mathrm{B} 2$ & 0.67 & 0.61 & reference item \\
(FLEX) & $\mathrm{B} 3$ & 0.60 & 0.35 & item fit \\
& $\mathrm{B} 8$ & 0.59 & 0.35 & item fit \\
& $\mathrm{B} 18$ & 0.64 & 0.41 & item fit \\
Elaboration & $\mathrm{B} 9$ & 0.54 & 0.29 & reference item \\
(ELA) & $\mathrm{B} 16$ & 0.79 & 0.62 & item fit \\
& $\mathrm{B} 17$ & 0.67 & 0.45 & item fit \\
Originality & $\mathrm{B} 1$ & 0.78 & 0.39 & reference item \\
(ORI) & $\mathrm{B} 6$ & 0.43 & 0.18 & item fit \\
Fluency (FLUEN) & $\mathrm{B} 10$ & 1.00 & 1 & reference item \\
\hline
\end{tabular}

The result of the CFA produced a standardized loading factor and was determined as the construct validity. When the loading factor value of the indicator is over 0.30 , the indicator is considered as significant (Igbaria et al., 1997, p. 290). Table 7 shows that all of the items have a loading factor value $>0.30$. Item 16 has the highest contribution to the measuring instrument with a loading factor of 0.79 , while item 6 gives the smallest contribution with a loading factor of 0.43 .
Discussion

All results of the analysis show that the sample size of 95 (3 of science classes) used in this factor analysis is sufficient. It can be seen from $\mathrm{KMO}$ value $>0.5$ (0.857). This is reinforced by the theory stated by Gable (1986) that the sample size or the number of respondents is 5 to 10 times the number of items. The item number or item in the trial is 18 , so the minimum sample size is 90 . In other words, a sample size of 95 is sufficient. 
The approach used to determine the number of factors obtained in this study is based on eigenvalues, variance percentages, and scree plots. Eigenvalues show the number of variations related to a factor. Factors that have eigenvalues greater than or equal to 1 will be maintained and factors that have eigenvalues less than 1 will not be included in the model because variables with values less than 1 are not better than the original variables (Supranto, 2004). From the result of the eigenvalues, it is known that those variables in the instrument can explain $56.116 \%$ the variances. It means that the instrument has already been able to measure the aspect that will be measured.

Based on the findings, it is indicated that after construct validity was done, the items of the instrument were reduced, from 18 items to 10 items. The selected items are grouped into five factors. Every factor is named base on the same between items and aspect that will be measured.

Factor 1 is called flexibility because the variables incorporated in these factors consist of variables that show a person's ability to adjust keyword and picture that are in accordance with the students' own understanding to explain the material, and able to relate the whole material so the people who read it will understand. Factor 2 is called elaboration because the variables incorporated in these factors show how student able to detail a main idea of the material as detailed as possible so that all things about the material can be contained in the mind map and still relevance.

Factor 3 is called originality because it consists of variables which indicate the authenticity of the idea in making mind maps by using the keywords that are their own characteristic and using various colors which fit with their creativity. Factor 4 is called fluency, which is seen from using time in making a mind map.

From the findings, it is found out that to assess the ability to think creatively through mind map creation, we can see it by judging from the originality of ideas, fluency in pouring and connecting ideas and the speed of expressing ideas, how to elaborate a material, and flexibility in displaying ideas with their own approach. Those are same with previous research that creative thinking skill can be measured from originality, fluency, flexibility, and elaboration (Hartati et al., 2017; Kristiani et al., 2017; Putri, 2016).

Several items are not incorporated in the initial aspect or factor. This is the purpose of the construct validity with EFA. EFA is grouping the variables (items) that have the same correlation to measure the same construct (Hair, Black, Babin, \& Anderson, 2010).

Half of the initial items in the instrument are not used after the construct validity test. Out of it all of the items have anti-image value $>0.5$. It can occur due to the lack of variants in the data collected. To construct validity test with EFA, every item has a minimal ideal value of factor loading, which is 0.55 for small scale test, and 0.35 for big scale test (Hair et al., 2010). The factor loading 0.55 if the trial subjects are 100 and 0.35 need 250 subjects. It is the shortcoming of the research. The research still needs more trial subject. Future research is suggested to use more subject trial to do the construct validity with EFA.

Reliability calculation of assessment instruments of mind-map product to measure students' creative thinking ability is done after conducting content validity and construct validity. The items that have been selected through the validity process are the estimated reliability estimates. Reliability calculations use the SPSS program with the Cronbach's Alpha technique. Cronbach's Alpha was chosen to estimate the instrument's reliability with a polytomous score (Retnawati, 2015, p. 91). The results of the reliability calculation of the mind-map product assessment instrument with ten items, using Cronbach's Alpha in the SPSS program amounted to 0.774 . It shows that the reliability of the instrument is good or the instrument has been reliable.

Model Fit testing Goodness of Fit (GOF) is obtained to test whether the initial model has fitness with the sample data or not. The model fit of the instrument is indicated by the $\mathrm{p}$-value $=0.68(\mathrm{p}>0.05), \mathrm{RMSEA}=0.00$ $($ RMSEA $<0.08)$ and Goodness of Fit Index = 0.94. Chi-square value is $28.66\left(\chi^{\wedge} 2=28.66\right)$ with a degree of freedom is $33\left(0 \leq \chi^{\wedge} 2 \leq\right.$ $2 \mathrm{df}$. 
Chi-square and p-value are to test the structural equation model fitness. Root Mean Square Error of Approximation (RSMEA), a measure of approximate fit of a model in the population, is related to differences in estimates (Riadi, 2018). Browne and Cudeck in Riadi (2018) classify 'close fit' if RSMEA value between 0.05 until 0.08 as 'adequate fit', and RSMEA between 0.08 until 0.10 as 'mediocre fit', but if RSMEA $>0.10$ could not accept. $\mathrm{Hu}$ and Bentler (1998) suggest that RSMEA value $<0.06$ as a cutoff criterion. Based on the result, RSMEA value for this instrument is in 'close fit' category.

The goodness of Fit Index (GFI) has a value between 0 until 1. GFI $>0.90$ is 'good fit', $0.80<$ GFI $<0.90$ is 'marginal fit' or it can be accepted. Based on the result, GFI value is 0.94 , so it means that it is in the 'good fit' category. Another evidence that the model is fit with the data is all of the items has loading factor value $>0.3$. Item 16 has the highest contribution to the measuring instrument with a loading factor of 0.79 , while item 6 gives the smallest contribution with a loading factor of 0.43 .

Item 16 is included in elaboration factor. Elaboration is an ability to develop an idea and add or detailing from an object, idea, or situation, so it makes it more interesting (Munandar, 2009). In other words, to know the creative thinking skill, it can be seen from how to elaborate an idea in a mind map.

The instrument developed can be one of way to assess student' creative thinking skill in biology subject, because that was a reliable instrument. This instrument also can be a reference for a teacher who wants to develop a product of assessment instrument.

Limitation in this research are as follows. (1) The use of classic tests compared to item response theory (IRT) due to the limited number of samples used does not allow the use of an IRT. (2) The use of EFA (exploratory factor analysis) and CFA (confirmatory factor analysis) is because the researchers formed new item indicators so that they did not know the latent variables where the indicators would group. CFA was also used to test whether the indicators that have been grouped based on the latent variable (con- struct) are consistent in the construct or not. (3) The try out of the instrument was not conducted in the school observed by the researchers when need analysis was done. The researchers tried out the instrument in MAN 3 Sleman, because of limited time. However, before the researchers do the tryout, they have interviewed the biology teacher in that school, who stated the same problems with the schools observed before.

\section{Conclusion}

From the findings and discussion, some conclusions are drawn. (1) Content validity results in the range number of CVR is $0.56-$ 1.00 , construct validity results to five factors that can assess students' creative thinking skill in biology subject, and the reliability estimate of the instrument is 0.774 . Therefore, it is concluded that the instrument which is developed in this research is valid and reliable to assess students' creative thinking skill in biology subject. (2) The p-value $=0.68$, RMSEA $=0.00$ and Goodness of Fit Index $=0.94$. (3) This instrument can be tried out for future research with more subjects (100-250 subjects) to know how valid and reliable this instrument is in large scale subjects. (4) The shortcoming of this research is the instrument was tried out just in one school. It is better if it is tried out in more than one school. (5) This instrument can be a reference for a teacher who wants to develop a product of assessment instrument. The instrument produced in this research can be used by the teacher to assess students' creative thinking skill with the heterogeneous students as a formative assessment in biology subject. Because the instrument contains statements to measure the creative thinking skill in general, then this instrument can be used in all the material in biology subject.

\section{Acknowledgment}

The researchers would like to thank to Indonesia Endowment Fund for Education (LPDP) from the Ministry of Finance of Republic of Indonesia for always supporting the first author by scholarship. 


\section{References}

Azwar, S. (2004). Reliabilitas dan validitas. Yogyakarta: Pustaka Pelajar.

Azwar, S. (2012). Reliabilitas dan validitas. Yogyakarta: Pustaka Pelajar.

Bilson, S. (2005). Analisis multivariat pemasaran. Jakarta: Gramedia Pustaka.

Buzan, T. (2011). Buku pintar mind map. Jakarta: PT Gramedia Pustaka Utama.

Çoban, S., \& Tokatli, E. S. (2017). The effect of mind mapping technique on students' achievements in music lesson and on their attitudes towards the mind mapping technique. Education and Science, 42(190), 423-435. https://doi.org/ 10.15390/EB.2017.6856

DePorter, B., \& Henarcki, M. (2010). Quantum teaching. Bandung: PT Mizan Pustaka.

Gable, R. K. (1986). Development in the affective domain. Boston, MA: Kluwer Nijhoff Publishing.

Guilford, J. P. (1950). Creativity. American Psychologist, 5(9), 444-454. http://dx.doi. org $/ 10.1037 /$ h0063487

Hair, J. F., Black, W. C., Babin, B. J., \& Anderson, R. E. (2010). Multivariate data analysis (7th ed.). Upper Saddle River, NJ: Prentice Hall.

Hartati, D. R., Asrial, \& Ernawati, D. W. (2017). Pengembangan instrumen penilaian berpikir kreatif peserta didik pada materi larutan asam dan basa kelas XI SMA/MA. Artikel Ilmiah, 1-10.

Herlina, L., \& Qurbaniah, M. (2017). Analisis kemampuan berpikir kreatif siswa pada materi virus kelas X MAS Al-Mustaqim Sungai Raya 2. Jurnal Bioeducation, 2(1), $11-14$.

Hu, L., \& Bentler, P. M. (1998). Fit indices in covariance structure modeling: Sensitivity to underparameterized model misspecification. Psychological Methods, 3(4), 424-453. https://doi.org/ 10.1037/1082-989X.3.4.424

Hudha, S. A., \& Mardapi, D. (2018). Developing an instrument for measuring the spiritual attitude of high school students. REiD (Research and Evaluation in Education), 4(1), 35-44. https:// doi.org/10.21831/reid.v4i1.20304

Hyerle, D. (2012). Peta pemikiran (thinking maps) sebagai suatu bahasa transformasional untuk pembelajaran. In N. D. Hyerle \& L. Alper (Eds.), Peta pemikiran (thinking maps): Penelitian berbasis sekolah, hasil dan model untuk prestasi dengan menggunakan peralatan visual (2nd ed.). (A. Cahyani, Trans.) Jakarta: PT. Indeks.

Igbaria, M., Zinatelli, N., Cragg, P., \& Cavaye, A. L. M. (1997). Personal computing acceptance factors in small firms: A structural equation model. MIS Quarterly, 21(3), 279-305. https://doi. org $/ 10.2307 / 249498$

Kristiani, K. D., Mayasari, T., \& Kurniadi, E. (2017). Pengembangan ssesmen keterampilan berpikir kreatif siswa SMP Negeri 5 Madiun pada materi cahaya dan alat optik. In Prosiding $S N F A$ (Seminar Nasional Fisika dan Aplikasinya) (pp. 102-108). Indonesia.

Laili, M., \& Otok, B. W. (2014). Second-order confirmatory factor analysis pada kemiskinan di Kabupaten Jombang. Jurnal Sains Dan Seni ITS, 3(2), 278-283. https://doi.org/10.12962/J23373520.V 3I 2.8161

Moore, K. D. (2015). Effective instructional strategies: From theory to practice (4th ed.). Los Angeles, CA: SAGE Publications.

Munandar, U. (2009). Pengembangan kreatifitas anak berbakat. Jakarta: Rineka Cipta.

Murley, D. (2007). Technology for everyone...: Mind mapping complex information. Law Journal Library, 99(1), 175-183.

Putri, A. R., Paidi, P., \& Subali, B. (2016). Kemampuan berpikir divergen keterampilan proses sains aspek biologi siswa SD berdasarkan lokasi sekolah. Jurnal Pendidikan Biologi, 5(5), 39-50.

Putri, L. O. L. (2016). Mind map sebagai model pembelajaran menilai penguasaan 
konsep dan alat evaluasi menilai kemampuan berpikir kreatif siswa. In Proceeding of Seminar Nasional Pendidikan dan Saintek (pp. 629-634). Surakarta: Universitas Muhammadiyah Surakarta. Retrieved from https://publikasiilmiah. ums.ac.id/handle/11617/7980

Regulation of Minister of Education and Culture, No. 14 of 2018, on Student Admissions (2018). Republic of Indonesia.

Retnawati, H. (2015). Validitas reliabilitas dan karakteristik butir (Panduan untuk peneliti, mahasiswa, dan psikometrian). Yogyakarta: Parama Publishing.

Riadi, E. (2018). Statistik SEM structural equation modeling dengan Lisrel. Yogyakarta: Andi.

Santrock, J. W. (2014). Psikologi pendidikan. (D. Angelica, Trans.). Jakarta: Salemba Humanika.

Sari, A. A., \& Jarnawi, A. D. (2008). Pengaruh pemberian tugas creative mind map setelah pembelajaran terhadap kemampuan kreativitas dan koneksi matematik siswa. In Proceeding of Seminar Nasional Matematika dan Pendidikan Matematika. Yogyakarta: Universitas Negeri Yogyakarta.
Sugiyono. (2015). Metode penelitian \& pengembangan. Bandung: Alfabeta.

Supardi, Haryanto, \& Suhendri, H. (2014). Pengembangan instrumen pengukuran karakter kreativitas siswa. In Proceeding of Seminar Nasional Hasil-Hasil Penelitian (SNHP-IV) Lembaga Penelitian dan Pengabdian Kepada Masyarakat Universitas PGRI Semarang (pp. 290-297). Semarang.

Supranto. (2004). Analisis multivariat arti dan interpretasi. Jakarta: Rineka Cipta.

Yong, A. G., \& Pearce, S. (2013). A beginner's guide to factor analysis: Focusing on exploratory factor analysis. Tutorials in Quantitative Methods for Psychology, 9(2), 79-94. https://doi.org/ 10.20982/tqmp.09.2.p079

Yusnaeni, Corebima, A. D., Susilo, H., \& Zubaidah, S. (2017). Creative thinking of low academic student undergoing search solve create and share learning integrated with metacognitive strategy. International Journal of Instruction, 10(2), 245-262. https://doi.org/10.12973/iji. 2017.10216a 